\title{
Zonasi, Keanekaragaman dan Pola Migrasi Ikan di Sungai Keyang, Kabupaten Ponorogo, Jawa Timur
}

\author{
Vivin Alfyana Yulia Pratami ${ }^{1}$, Prabang Setyono ${ }^{2}$, Sunarto ${ }^{3}$ \\ 1Program Studi Biosain, Fakultas Pascasarjana, Universitas Sebelas Maret Surakarta, email: \\ vivin.alfyana19@gmail.com \\ 2Pascasarjana Universitas Sebelas Maret Surakarta (email: prabangsetyono@gmail.com) \\ 3Pascasarjana Universitas Sebelas Maret Surakarta (email: rm.sunarto@yahoo.co.id)
}

\begin{abstract}
ABSTRAK
Ikan adalah salah satu biota air yang rentan terhadap perubahan kondisi lingkungan, sehingga dapat digunakan sebagai indikator lingkungan. Penelitian ini bertujuan untuk mengetahui zonasi, keanekaragaman, serta pola migrasi ikan di Sungai Keyang, Kabupaten Ponorogo. Penelitian dilakukan pada bulan Oktober-November 2017 dengan metode purposive sampling pada 3 stasiun pengamatan. Pengukuran faktor fisika kimia air meliputi suhu, pH, DO, BOD, $\mathrm{CO}_{2}$, kekeruhan, kecerahan, serta padatan terlarut (TDS). Hasil penelitian yang diperoleh yaitu di Sungai Keyang terdapat 6 famili dan 11 spesies ikan. Famili tersebut adalah Poecilidae, Cyprinidae, Balitoridae, Sisoridae, Anantidae, serta Channidae. Spesies yang ditemukan yaitu Poecilia reticulata, Rasbora argyrotaenia, Rasbora dusonensis, Rasbora paviana, Rasbora tornieri, Puntius amphibious, Poropontius tawarensis, Nemacheilus fasciatus, Glyptothorax platypogon, Anabas testudineus, dan Channa striata. Spesies yang memiliki nilai kepadatan tertinggi yaitu $P$. reticulata sebanyak 39 individu dan $R$. dusonensis sebanyak 27 individu pada stasiun 2 dan 17 individu pada stasiun 3. Indeks keanekaragaman ikan pada semua stasiun termasuk dalam kategori sedang yaitu secara berturut-turut 1,$57 ; 1,80$; dan 1,45 . Indeks kemerataan ikan di semua stasiun termasuk dalam kategori tinggi yaitu 1,64; 1,73; dan 1,87, sedangkan indeks dominansi ikan termasuk dalam kategori rendah yaitu secara bertutut-turut 0,28; 0,23; dan 0,28. Simpulan dari penelitian ini adalah zonasi persebaran ikan di Sungai Keyang didominasi oleh genus Poecillia dan Rasbora, keanekaragaman ikan termasuk dalam kategori sedang, serta pola migrasi masing-masing spesies ikan berbeda yaitu ada yang selalu di tepi dan ada yang menyebar baik untuk tujuan reproduksi atau mencari makan.
\end{abstract}

Kata kunci: keanekaragaman ikan, pola migrasi ikan, Sungai Keyang, zonasi

\begin{abstract}
Fish is one of the water organism that susceptible to change of environmental condition, so it is can be used as bioindicator of environmental pollution. This research is purposed to determine the spread zonation, diversity, and migration structure of fish in Keyang River, Ponorogo Regency. Sample was conducted in OctoberNovember 2017with purposive sampling method in 3 observation stations. The results of this research were 6 families and 11 species. The families are Poecilidae, Cyprinidae, Balitoridae, Sisoridae, Anantidae, and Channidae. The species were found Poecilia reticulata, Rasbora argyrotaenia, Rasbora dusonensis, Rasbora paviana, Rasbora tornieri, Puntius amphibious, Poropontius tawarensis, Nemacheilus fasciatus, Glyptothorax platypogon, Anabas testudineus, and Channa striata. The highest density species are P. reticulata with 39 individual and R.dusonensis with 27 individual at station 2 and 17 individual at station 3 . The diversity index of fish in all observation stations was included in medium category $(1,57 ; 1,80$; and 1,45$)$. The similarity index (Evennes index) in all stations was included in high category $(1,64 ; 1,73$; and 1,87). The Simpson's index in all stations was included in low category $(0,28 ; 0,23$; and 0,28$)$. The conclusions of this research are Poecillia and Rasbora was dominated the fish spread zonation, diversity of gastropods in Keyang River included in medium category, and each spesies had different migration structure, that are at the side or spead of the river with the purpose for reproduction or looking for food.
\end{abstract}

Keywords: fish biodiversity, fish migration structure, Keyang River, zoning

Citation: Pratami, V. A. Yulia., Setyono, P dan Sunarto. (2018). Zonasi, Keanekaragaman Dan Pola Migrasi Ikan Di Sungai Keyang, Kabupaten Ponorogo, Jawa Timur. Jurnal Ilmu Lingkungan. 16(1), 78-85, doi:10.14710/jil.16.1.78-85

\section{Pendahuluan}

Sungai dapat artikan sebagai suatu tempat atau lokasi mengalirnya air yang berasal dari sumber mata air hingga ke muara yang dibatasi oleh adanya garis sempadan pada sisi kanan dan kirinya. Sungai termasuk ke dalam ekosistem air tawar yang memiliki peran penting diantaranya sebagai sumber air minum, untuk kegiatan pertanian dan perikanan, industri, pemurnian limbah rumah tangga, serta 
Pratami, V. A. Yulia., Setyono, P dan Sunarto. (2018). Zonasi, Keanekaragaman Dan Pola Migrasi Ikan Di Sungai Keyang, Kabupaten Ponorogo, Jawa Timur. Jurnal IImu Lingkungan. 16(1), 78-85, doi:10.14710/jil.16.1.78-85

sebagai habitat berbagai macam organisme air (Astirin dan Ahmad, 2000).

Ponorogo merupakan salah satu kabupaten di Jawa Timur yang berada pada ketinggian 90-199 $\mathrm{m}$ di atas permukaan laut. Sungai yang terdapat di kabupaten ini salah satunya yaitu Sungai Keyang, tepatnya di Desa Ngindeng, Kabupaten Ponorogo, Jawa Timur. SubDAS Keyang merupakan bagian dari SubDAS Kali Madiun yang termasuk salah satu SubDAS dari DAS Bengawan Solo. Sungai Keyang terletak dekat dengan area pemukiman serta pertanian. Hal ini memberikan dampak yang positif maupun negatif untuk wilayah itu sendiri. Dampak positifnya yaitu meningkatkan perekonomian warga, sedangkan dampak negatifnya yaitu adanya limbah domestik dan senyawa organik yang masuk ke aliran sungai (Haji dkk., 2012). Senyawa organik dapat berasal dari sisa-sisa pertanian, limbah rumah tangga, limbah industri, serta dari kotoran manusia dan hewan. Meningkatnya senyawa organik pada perairan dapat berakibat buruk yaitu terjadinya ledakan fitoplankton dan berkurangnya kandungan oksigen terlarut (Dissolved Oxygen/DO) serta berakibat pada kematian ikan dan organisme air lainnya (Grosse et al., 2015).

Ikan merupakan salah satu organisme air yang rentan terhadap perubahan lingkungan. Setiap spesies ikan memiliki karakter habitat yang berbeda agar dapat hidup dan berkembangbiak. Struktur komunitas ikan akan mengalami perubahan atau gangguan jika kualitas air terganggu. Adanya perubahan pada keanekaragaman ikan dapat digunakan sebagai bioindikator pencemaran (Azmi dkk., 2015).

Sehubungan dengan hal tersebut, maka penelitian ini bertujuan untuk mengetahui zonasi, keanekaragaman, serta pola migrasi ikan di Sungai Keyang, Kabupaten Ponorogo.

\section{Metode Penelitian}

Penelitian ini dilakukan pada bulan OktoberNovember 2017 di Sungai Keyang, Ponorogo. Analisis kualitas fisik kimia air dilakukan di lokasi pengambilan sampel, identifikasi ikan di UPT Laboratorium Terpadu, Universitas Sebelas Maret. Penentuan stasiun dilakukan dengan metode Purposive Sampling. Terdapat 3 stasiun pengamatan, yaitu stasiun 1 terletak pada $7^{056}$ 02.06"S dan $111^{035}$ '05.78"T, stasiun 2 terletak pada 7056'00.09"S, dan 111034'59.31"T, dan stasiun 3 terletak pada 7055'52.54"S, dan 111034'55.35"T.

Alat yang digunakan dalam penelitian adalah jaring ikan, jala tebar, pancing, termometer, pHmeter, turbidimeter, botol Winkler gelap dan terang, Erlenmeyer, timbangan digital, sacchi disk, spuit $1 \mathrm{ml}$, botol air mineral, plastik, corong, dan buku identifikasi. Bahan yang digunakan adalah air sungai, alkohol $70 \%$, formalin $4 \%, \mathrm{H}_{2} \mathrm{SO}_{4}, \mathrm{MnSO}_{4}, \mathrm{KOH}-\mathrm{KI}$,
$\mathrm{Na}_{2} \mathrm{~S}_{2} \mathrm{O}_{3}$, larutan $\mathrm{PP}$, metilen blue, $\mathrm{NaOH}$, kertas saring, dan kertas millimeter.
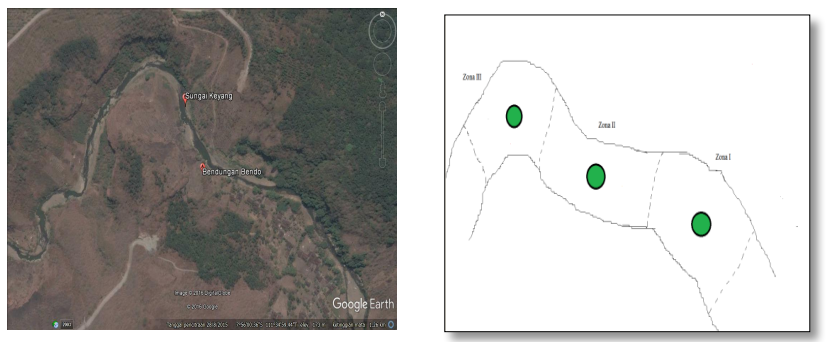

Gambar 1. Lokasi Stasiun Penelitian di Sungai Keyang, Ponorogo

\subsection{Pengambilan Data}

Pengambilan sampel ikan dilakukan pada 3 stasiun pengamatan. Ikan ditangkap menggunakan jala tebar, jaring ikan, dan pancing. Jala tebar dan jaring dipasang selama 6 jam, ikan yang tertangkap pada setiap lokasi diawetkan dengan formalin $4 \%$ untuk diidentifikasi menggunakan buku Kottelat et al. (1993), kemudian dipisahkan dan dihitung sesuai jenisnya. Pengukuran faktor lingkungan terdiri dari suhu, $\mathrm{pH}, \mathrm{DO}, \mathrm{BOD}, \mathrm{CO}_{2}$, kekeruhan, kecerahan, dan TDS.

\subsection{Analisis Data}

Hasil pengamatan ikan yang diperoleh kemudian dianalisis dengan:

a. Kerapatan

Nilai kerapatan dilakukan untuk mengetahui jumlah individu dalam satu luas wilayah.

$$
\mathrm{K}=\frac{\text { jumlah } \text { individu }}{\text { luas seluruh petak pengamatan }}
$$

b. Indeks Keanekaragaman Shannon Whienner $\left(\mathrm{H}^{\prime}\right)$

Penghitungan indeks keanekaragaman bertujuan untuk mengetahui keanekaragaman spesies di setiap stasiun pengamatan.

$$
H^{\prime}=\sum p i \log p i \rightarrow p i=\frac{n}{N}
$$

Keterangan:

$$
\begin{aligned}
& \mathrm{H}^{\prime}=\text { Keanekaragaman Shannon-Winner } \\
& \mathrm{Pi}=\text { Indeks kemelimpahan } \\
& \mathrm{n}=\text { Jumlah individu tiap spesies } \\
& \mathrm{N}=\text { Jumlah total seluruh jenis }
\end{aligned}
$$

c. Indeks Kemerataan Shannon-Evenness (E)

Indeks kemerataan menunjukkan merata atau tidaknya sebaran ikan di suatu perairan. Jika indeks kemerataannya tinggi maka dapat dikatakan persebaran masing-masing spesies merata. 


$$
E=\frac{H^{\prime}}{\log S}
$$

Keterangan:

$\begin{array}{ll}\mathrm{E} & =\text { Indeks kemerataan Shannon-Evenness } \\ \mathrm{H}^{\prime} & =\text { Indeks Keanekaragaman Shannon-Winner }\end{array}$

d. Indeks Dominansi Simpson's (C)

Indeks dominansi menunjukkan besarnya dominansi sebaran ikan dalam suatu perairan. Jika dominansi tinggi maka dalam habitat tersebut terdapat spesies yang mendominasi, kondisi lingkungan tidak stabil, dan terjadi tekanan ekologi terhadap ikan.

$$
\mathrm{C}=\sum \mathrm{Pi}^{2} \text { dengan } \mathrm{Pi}=\frac{n i}{N}
$$

Keterangan:

$$
\begin{array}{ll}
\mathrm{D} & =\text { Indeks dominansi Simpson's } \\
\mathrm{ni} & =\text { Jumlah individu suatu jenis } \\
\mathrm{N} & =\text { Jumlah individu seluruh jenis }
\end{array}
$$

Selanjutnya untuk mengetahui perbedaan signifikan pada kemelimpahannya, sampel dianalisis menggunakan uji T. Analisis korelasi dan regresi dilakukan untuk mengetahui hubungan antara keanekaragaman ikan dengan faktor fisik kimia.

\section{Hasil dan Pembahasan}

Hasil penelitian menunjukkan bahwa di Sungai Keyang terdapat 6 famili dan 11 spesies ikan. Adapun famili tersebut adalah Poecilidae, Cyprinidae, Balitoridae, Sisoridae, Anantidae, serta Channidae. Famili Poecilidae terdiri dari satu spesies yaitu Poecilia reticulata. Famili Cyprinidae terdiri dari 6 spesies, yaitu Rasbora argyrotaenia, Rasbora dusonensis, Rasbora paviana, Rasbora tornieri, Puntius amphibious, serta Poropontius tawarensis. Famili Balitoridae terdiri dari satu spesies yaitu Nemacheilus fasciatus, famili Sisoridae terdiri dari satu spesies yaitu Glyptothorax platypogon, famili Anabantidae memiliki satu spesies yaitu Anabas testudineus, dan famili Channidae juga memiliki satu spesies yaitu Channa striata (Tabel 1).

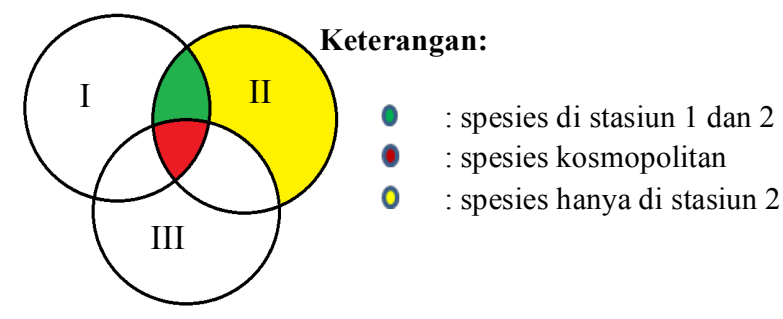

Gambar 2. Zonasi Keragaman Ikan di Sungai Keyang

Stasiun pengamatan yang berbeda juga berpengaruh terhadap keanekaragaman spesies serta jumlah individu pada setiap spesies. Hal ini berkaitan dengan faktor fisika kimia yang juga berbeda pada setiap stasiun pengamatan. Masing-masing spesies memiliki karakter habitat serta tingkat toleransi yang berbeda terhadap perubahan kondisi lingkungan. Stasiun 1 terdiri dari 9 spesies dengan jumlah individu paling banyak dibandingkan stasiun yang lain yaitu sebanyak 88 individu. Stasiun 2 terdiri dari 11 spesies dengan jumlah 71 individu, sedangkan pada stasiun 3 terdiri dari 6 spesies dengan jumlah 41 individu (Tabel 1).

Berdasarkan data tersebut maka dapat diketahui zonasi persebaran ikan seperti pada Gambar 2 . Spesies yang bersifat kosmopolitan (terdapat di semua lokasi) yaitu $P$. reticulata, $P$. amphibious, $R$. dusonensis, $R$. paviana, $R$. argyrotaenia dan $C$. striata. Spesies dengan distribusi sedang (terdapat di stasiun 1 dan 2) yaitu $P$. tawarensis, $R$. tornieri, dan $A$. testudineus. Spesies yang berdistribusi sempit (hanya terdapat pada satu lokasi pengamatan yaitu $N$. fasciatus dan G. platypogon.

Channa striata merupakan salah satu spesies yang dapat ditemukan di semua lokasi pengamatan. Hal ini karena spesies ini mampu menyesuaikan dengan kondisi lingkungan air. C. striata dapat menghirup udara dari atmosfer karena memiliki labirin di atas insangnya sehingga mampu bertahan lebih lama dan mampu bergerak dalam jarak yang jauh Chandra dan Tarun (2004). Selain itu, C. striata mampu menyesuaikan dan bertahan dalam perubahan kondisi lingkungan salah satunya pada kadar oksigen terlarut (DO) yang rendah. C. striata pada umumnya ditemukan pada perairan dangkal seperti sungai dengan kedalaman sekitar $40 \mathrm{~cm}$, dengan arus air yang tidak terlalu cepat. Kondisi tersebut sesuai dengan lingkungan pengamatan yang tidak terlalu dalam dan arus tidak terlalu cepat (Listyanto dan Septyan, 2009).

Frekuensi $C$. striata yang tinggi juga disebabkan karena spesies ini termasuk dalam hewan karnivora, sehingga memiliki mobilitas yang tinggi dalam mencari makanan misalnya udang dan ikan-ikan kecil (Kuan-Chung et al., 2016)). Udang dan ikan kecil ini juga bersifat mobile (berpindah tempat), sehingga $C$. striata juga memiliki mobilitas tinggi untuk mendapatkan makanan tersebut dan akibatnya $C$. striata dapat ditemukan di semua lokasi pengamatan.

$P$. reticulata atau yang dikenal dengan ikan gatul merupakan ikan air tawar yang dapat menyesuaikan dengan berbagai kondisi lingkungan termasuk lingkungan tercemar (Araujo et al., 2003). Adanya pencemaran air di sungai dapat mempengaruhi struktur populasi $P$. reticulata, sehingga jumlah individu spesies tersebut mengalami peningkatan. Spesies $P$. amphibious, $R$. dusonensis, $R$. paviana, dan $R$. argyrotaenia termasuk dalam satu famili yaitu Cyprinidae (golongan ikan wader). Ikan wader pada umumnya terdapat pada aliran air yang tidak terlalu deras seperti selokan, sungai dan tambak. Spesies ini tergolong dalam benthopelagik, hidup di perairan tawar daerah tropis dengan $\mathrm{pH}$ berkisar 6,0-6,5 (Nelson et al., 2010). 
Tabel 1. Keanekaragaman Ikan di Sungai Keyang, Ponorogo

\begin{tabular}{|c|c|c|c|c|c|}
\hline \multirow[t]{2}{*}{ Famili } & \multirow[t]{2}{*}{ Spesies } & \multirow[t]{2}{*}{ Nama lokal } & \multicolumn{3}{|c|}{ Stasiun pengamatan } \\
\hline & & & 1 & 2 & 3 \\
\hline Poecilidae & Poecilia reticulata & Ikan gatul & 39 & 19 & 12 \\
\hline \multirow[t]{6}{*}{ Cyprinidae } & Rasbora argyrotaenia & Wader pari & 12 & 4 & 3 \\
\hline & Rasbora dusonensis & Ikan seluang & 21 & 27 & 17 \\
\hline & Rasbora paviana & $\begin{array}{l}\text { Ikan } 1 \text { (sirip kuning } \\
\text { dengan bercak ekor) }\end{array}$ & 7 & 2 & 3 \\
\hline & Rasbora tornieri & Ikan 2 (sirip orange) & 2 & 3 & - \\
\hline & Puntius amphibious & Ikan 3 (perak titik di ekor) & 2 & 3 & 5 \\
\hline & Poropontius tawarensis & Ikan kawan & 2 & 1 & - \\
\hline Balitoridae & Nemacheilus fasciatus & Ikan uceng & - & 5 & - \\
\hline Sisoridae & Glyptothorax platypogon & Ikan kehkel & 2 & 2 & - \\
\hline Anabantidae & Anabas testudineus & Ikan betik (betok) & 2 & 2 & - \\
\hline Channidae & Channa striata & Ikan gabus & 1 & 3 & 1 \\
\hline \multicolumn{3}{|c|}{ TOTAL } & 88 & 71 & 41 \\
\hline
\end{tabular}

Rasbora argyrotaenia dapat ditemukan di semua lokasi karena mampu menyesuaikan dengan kondisi lingkungan yang ekstrim. Spesies ini mampu menyesuaikan dengan kadar DO yang rendah dengan cara meningkatkan afinitas darah terhadap oksigen. Jika kuat arus sangat deras, $R$. argyrotaenia beradaptasi dengan cara berlindung di balik bebatuan dan berusaha berenang melawan arus (Hartoto dan Mulyana, 1996).

Glyptothorax platypogon susah ditemukan karena ikan ini lebih suka bersembunyi di dalam liang sungai misalnya di bebatuan untuk tempat hidupnya dan lebih suka menyukai arus dengan kecepatan yang sedang hingga deras (Djajasmita dkk., 1987). Hal lain yang berpengaruh adalah rendahnya fekunditas spesies ini yang hanya berkisar 104-920 butir karena tidak bisa menghindar dari serangan predator atau parasit. Selain itu, masa pemijahan G. platypogon berkisar antara bulam Maret-Agustus, sedangkan penelitian dilaksanakan pada bulan oktober yang berarti bahwa spesies ini sedang tidak dalam masa pemijahan sehingga jumlahnya sedikit. Menyusutnya volume air sungai diikuti dengan banyaknya serangga air yang akan memangsa telur G. platypogon.

Kerapatan masing-masing spesies ikan di Sungai Keyang bervariasi. Pada stasiun 1, nilai kerapatan tertinggi yaitu dimiliki oleh spesies $P$. reticulata sebesar 2,5 individu/ $\mathrm{m}^{2}$. Pada stasiun 2 dan 3, kerapatan tertinggi yaitu spesies $R$. dusonensis sebanyak 2,17 individu/ $\mathrm{m}^{2}$ dan 28,3 individu/ $\mathrm{m}^{2}$.

Kerapatan $P$. reticulata tergolong tinggi berkaitan dengan masa reproduksi atau pemijahannya. $P$. reticulata memiliki masa kehamilan yang relatif pendek yaitu berkisar 21-30 hari. Seekor ikan $P$. reticulata dapat melahirkan anak antara 2-100 ekor pada setiap kelahiran (rata-rata 30 ekor). Beberapa jam setelah melahirkan, induk $P$. reticulata sudah siap untuk dibuahi lagi. Kemampuan reproduksi dan masa kehamilan yang pendek dapat menyebabkan $P$. reticulata semakin sering melahirkan, dan anak yang dihasilkan juga semakin banyak, akibatnya jumlah individu $P$. reticulata meningkat dan kerapatan juga meningkat (Lubis dan Sri, 2013).
Berdasarkan gambar di atas dapat diketahui pola migrasi ikan. Migrasi merupakan proses perpindahan ikan ke suatu tem pat yang sesuai untuk tetap bertahan hidup, tumbuh serta berkembangbiak. Migrasi merupakan pergerakan suatu spesies pada stadia tertentu dalam jumlah banyak ke suatu wilayah. Terdapat tiga lokasi atau habitat sebagai tujuan migrasi ikan yaitu tempat untuk bereproduksi, tempat untuk makan, dan tempat untuk berlindung dari predator (Fahmi, 2010).

Setiap spesies ikan memiliki pola migrasi yang berbeda, ada yang lebih suka berada di tepi ataupun menyebar di badan air. Spesies $C$. striata dapat ditemukan di semua lokasi pengamatan karena memiliki daya migrasi yang tinggi yang bertujuan untuk mencari makan serta melindungi diri dari predator. Hal ini dapat dilihat dari habitat C. striata yang lebih suka sembunyi di bawah batu atau tanaman air. Bentuk tubuh ikan yang hampir oval dan panjang mempermudah pergerakan ikan untuk berpindah tempat dan bersembunyi.

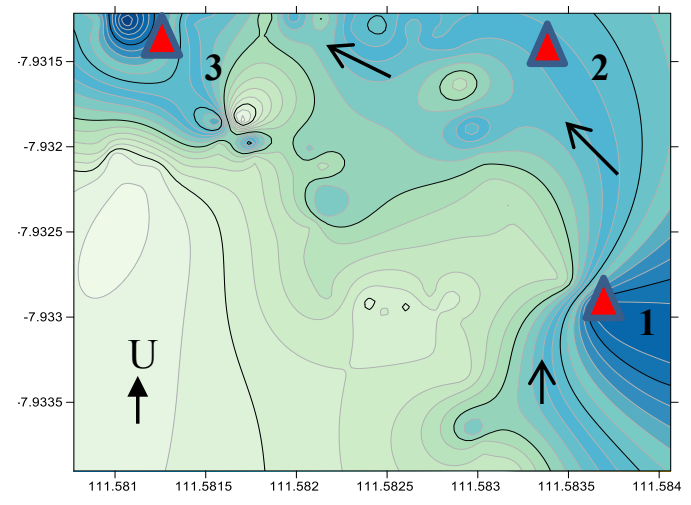

$$
\begin{aligned}
& \text { Keterangan: } \\
& \quad \quad=\text { stasiun pengamatan } \\
& \rightarrow \quad=\text { arus air } \\
& \text { Kemelimpahan ikan (indv): } \\
& \square \quad 88 \text { (Zonasi Poecilia) } \\
& \square \quad 71 \text { (Zonasi Rasbora) } \\
& \square \quad 41 \text { (Zonasi Rasbora) }
\end{aligned}
$$

Gambar 3. Overlay Persebaran Ikan di Sungai Keyang 
Ikan betik (A. testudineus) melakukan migrasi dengan tujuan utama yaitu mencari makan dan untuk melakukan pemijahan. Migrasi biasanya terjadi malam hari dan setelah hujan. Ikan betik menyukai daerah dengan suhu berkisar $15-31^{\circ} \mathrm{C}$ (Dinas Perikanan Provinsi Jambi, 1995). Proses migrasi ikan untuk reproduksi terjadi pada saat sebelum memasuki tahap spawning (pengeluaran telur dan sperma serta pembuahan telur oleh sperma) dan juga untuk membuat sarang. Tempat yang baik untuk memijah yaitu memiliki ketersediaan makanan yang cukup, aman dari predator, keadaan substrat misalnya batu-batuan, pasir, lumpur atau tanaman air. Ikan betik dapat ditemukan di semua lokasi pengamatan terutama di bagian tengan badan sungai yang terdapat substrat batu dan pasir, sehingga sesuai untuk proses pemijahannya.

Ikan gatul $(P$. reticulata) ditemukan di semua lokasi pengamatan dan berada di tepi sungai baik air yang menggenang ataupun mengalir. Tubuhnya yang kecil memudahkan pergerakan, serta mampu hidup pada tempat yang tercemar atau kotor. Ikan kehkel (G. platypogon) mampu bertahan dalam arus air yang deras karena adanya struktur lipatan kulit di bagian bawah perutnya. Larva atau anakan menempel di substrat seperti bebatuan, sehingga mobilisasinya tidak terlalu tinggi yaitu hanya ditemukan pada stasiun 1 dan stasiun 2 (Hartoto dan Mulyana, 1996).

Golongan wader atau genus Rasbora memiliki pola migrasi yang hampir sama. Rasbora melakukan migrasi untuk mendukung pemijahan. Ikan bermigrasi ke permukaan atau bagian bawah sungai untuk memijah di habitat yang sesuai. Pada musim penghujan, wader pari yang sebelumnya hidup di daerah lindungan pindah ke daerah atas sungai yang memiliki substrat kerikil, pasir dan batu-batuan. Selama melakukan migrasi, Rasbora memakan fitoplankton dan zooplankton (Djumanto dan Setyawan, 2009). Semua lokasi pengamatan memiliki substrat dasar berbatu dan berpasir yang cocok untuk pemijahan. Pada saat masih dalam tahapan larva, ikan ini mudah terbawa arus sehingga menyebar ke semua badan air sungai, sedangkan pada tahap dewasa pergerakannya melawan arus (Sentosa dan Djumanto, 2010).

\section{Indeks Keanekaragaman $\left(\mathrm{H}^{\prime}\right)$, Kemerataan (E), dan Dominansi (C)}

Berdasarkan hasil perhitungan dapat diketahui bahwa indeks keanekaragaman ikan di stasiun 1, stasiun 2, dan stasiun 3 termasuk dalam kategori sedang yaitu dengan nilai masing-masing sebesar 1,57; 1,80; dan 1,45 (Tabel 2).

Tabel 2. Nilai Indeks Keanekaragaman $\left(\mathrm{H}^{\prime}\right)$, Kemerataan (E), dan Dominansi (C)

\begin{tabular}{cccc}
\hline Stasiun & $\mathbf{H}^{\prime}$ & E & C \\
\hline 1 & 1,57 & 1,64 & 0,28 \\
2 & 1,80 & 1,73 & 0,23 \\
3 & 1,45 & 1,87 & 0,28 \\
\hline
\end{tabular}

Hal ini berarti bahwa komunitas ikan di sungai ini memiliki kompleksitas yang sedang karena interaksi spesies yang terjadi di dalam komunitas tersebut cukup baik. Stasiun 2 memiliki keanekaragaman paling tinggi karena pada stasiun ini terdapat jumlah spesies yang paling banyak dan didukung oleh adanya faktor fisika kimia yang baik untuk kehidupan. Keanekaragaman spesies dapat digunakan untuk mengukur stabilitas komunitas, yaitu kemampuan suatu komunitas untuk selalu berada dalam keadaan stabil. Stabilitas suatu komunitas berhubungan dengan jumlah dan tingkat kompleksitas jalur energi dan nutrisi (Indriyamto, 2012). Semakin baik tingkat kompleksitasnya maka komunitas semakin stabil dan keanekaragaman semakin tinggi. Semakin tinggi nilai keanekaragaman maka nilai homogenitas semakin rendah dan nilai produktivitas spesies semakin tinggi.

Nilai indeks kemerataan ikan di setiap stasiun pengamatan bervariasi. Berdasarkan hasil perhitungan dapat diketahui bahwa indeks kemerataan ikan di stasiun 1, stasiun 2, dan stasiun 3 tergolong tinggi dengan nilai masing-masing sebesar 1,64; 1,73; dan 1,87 (Tabel 2). Hal ini berarti bahwa penyebaran spesies di Sungai Keyang merata dan tidak ada dominansi suatu spesies. Indeks kemerataan di zona 3 paling tinggi karena jumlah individu pada setiap spesiesnya memiliki selisih yang tidak terlalu banyak dan tidak ada satu spesies yang mendominasi spesies lain sehingga nilai kemerataannya tinggi.

Berdasarkan hasil perhitungan dapat diketahui bahwa indeks dominansi ikan di stasiun 1, stasiun 2, dan stasiun 3 termasuk kategori rendah dengan nilai masing-masing 0,28; 0,23; dan 0,28 (Tabel 2). Hal ini berarti bahwa tidak ada spesies yang secara nyata mendominasi spesies yang lain, kondisi lingkungan stabil serta tidak terjadi tekanan ekologi terhadap ikan di perairan tersebut. Apabila indeks dominansi tinggi, maka terjadi dominansi atau penguasaan oleh satu spesies, sedangkan jika nilai indeks dominansi rendah, maka penguasaan terdapat pada beberapa spesies (Indriyanto, 2012).

Pengukuran faktor fisika kimia dilakukan di lokasi pengamatan atau secara insitu. Suhu air berkisar $29-31^{\circ} \mathrm{C}$. Nilai tersebut masih berada dalam ambang batas yang baik untuk kehidupan organisme. Suhu di perairan ini cukup baik untuk mendukung kehidupan ikan seperti ikan kehkel (G. platypogon) yang memiliki kisaran suhu $24-30^{\circ} \mathrm{C}$, ikan P.reticulata dan ikan gabus (C. striata) dengan kisaran suhu 26$30^{\circ} \mathrm{C}$ sehingga dapat tumbuh dan berkembangbiak secara optimal.

Pada stasiun 1, kecerahan air sebesar $37,66 \mathrm{~cm}$, pada stasiun 2 yaitu $40 \mathrm{~cm}$, dan pada stasiun 3 yaitu $50 \mathrm{~cm}$. Berdasarkan nilai tersebut dapat dikatakan bahwa perairan di Sungai Keyang termasuk perairan keruh. Kondisi perairan dapat dibagi menjadi 3 kategori dilihat dari nilai kecerahannya, yaitu perairan keruh $(25-100 \mathrm{~cm})$, perairan sedikit keruh 
Pratami, V. A. Yulia., Setyono, P dan Sunarto. (2018). Zonasi, Keanekaragaman Dan Pola Migrasi Ikan Di Sungai Keyang, Kabupaten Ponorogo, Jawa Timur. Jurnal Ilmu Lingkungan. 16(1), 78-85, doi:10.14710/jil.16.1.78-85

$(100-500 \mathrm{~cm})$, dan perairan jernih $(>500 \mathrm{~cm})$. Tingkat kecerahan air ditentukan oleh adanya padatan terlarut, partikel, serta warna air (Munarto, 2010). Kandungan lumpur atau pasir yang terbawa arus juga menyebabkan menurunnya kecerahan air yang berakibat pada penurunan kualitas air (Wetzel and Gene, 2000). Kecerahan air ini juga berpengaruh terhadap proses reproduksi atau pemijahan ikan. Pada ikan $R$. dusonensis yang melakukan pemijahan pada musim pancaroba dengan kualitas air yang cukup baik dan air yang jernih.

Tabel 3. Hasil Pengukuran Parameter Fisika Kimia Air di Sungai Keyang

\begin{tabular}{llccccc}
\hline No & Parameter & \multicolumn{3}{c}{ Stasiun Pengamatan } & Rata-rata & Baku Mutu \\
& & $\mathbf{1}$ & $\mathbf{2}$ & $\mathbf{3}$ & & \\
\hline 1 & Suhu $\left({ }^{\circ} \mathrm{C}\right)$ & 30,6 & 30,3 & 29,6 & 30,2 & $28-32$ \\
2 & Kecerahan (cm) & 37,66 & 40 & 50 & 42,55 & - \\
3 & Kekeruhan (NTU) & 17,3 & 17,4 & 18,0 & 17,5 & - \\
4 & TDS (g/L) & 0,18 & 0,20 & 0,26 & 0,21 & 1,00 \\
5 & DO (mg/L) & 7,24 & 6,88 & 6,66 & 6,92 & 6,00 \\
6 & BOD (mg/L) & 1,05 & 0,84 & 1,37 & 1,08 & 2,00 \\
7 & $\mathrm{CO}_{2}(\mathrm{mg} / \mathrm{L})$ & 19 & 20,6 & 23,3 & 20,9 & - \\
8 & $\mathrm{pH}$ & 6 & 6 & 6 & 6 & $6-9$ \\
\hline
\end{tabular}

Keterangan:

Baku mutu faktor fisika dan kimia lingkungan perairan Sungai Keyang berdasarkan Peraturan Pemerintah No.82 Tahun 2001 Tentang Pengelolaan Kualitas Air dan Pengendalian Pencemaran Air.

Berdasarkan hasil pengukuran pada stasiun 1 kadar kekeruhannya sebesar 17,3 NTU, pada stasiun 2 sebesar 17,4 NTU, dan pada stasiun 3 sebesar 18 NTU. Nilai tersebut melebihi ambang batas sesuai SK MENKES No 907/MENKES/SK/VII/2002 dengan kadar maksimal kekeruhan yang diperbolehkan yaitu sebesar 5 NTU. Tingginya nilai kekeruhan ini berhubungan dengan padatan terlarut tersuspensi (TDS). Semakin tinggi TDS maka nilai kekeruhan juga semakin tinggi. Nilai kekeruhan yang tinggi mengakibatkan menurunnya intensitas cahaya yang masuk ke badan air sehingga proses fotosintesis berkurang dan organisme perairan akan mati karena kekurangan oksigen (Effendi, 2003). Hasil pengamatan menunjukkan bahwa kekeruhan berhubungan negatif atau berbanding terbalik dengan $\mathrm{H}^{\prime}$ ikan. Semakin tinggi kekeruhan maka keanekaragaman semakin rendah.

Berdasarkan hasil pengamatan, nilai TDS pada stasiun 1 yaitu sebesar $0,18 \mathrm{~g} / \mathrm{L}$, stasiun 2 sebesar $0,20 \mathrm{~g} / \mathrm{L}$, dan stasiun 3 sebesar $0,26 \mathrm{~g} / \mathrm{L}$. Nilai tersebut masih berada di bawah ambang batas sesuai PP No.82 Tahun 2001 yaitu sebesar 1 g/L. Hal ini berarti bahwa kondisi perairan masih layak untuk pertumbuhan dan perkembangan organisme air di wilayah tersebut. Penyebab utama adanya padatan terlarut yaitu pasir halus, lumpur, ataupun jasad renik yang terbawa arus air. Selain itu, TDS juga disebabkan oleh adanya bahan anorganik seperti sisa sabun dan detergen (Weber and Lawrence, 2007). TDS berhubungan terbalik atau negatif terhadap keanekaragaman ikan. Hal ini berkaitan dengan kekeruhan dan kadar DO perairan. Semakin tinggi TDS maka kekeruhan semakin tinggi, fotosintesis berkurang dan akibatnya kadar DO berkurang. Organisme di dalam perairan kekurangan oksigen dan dapat menyebabkan kematian.

Oksigen terlarut (DO) merupakan jumlah oksigen yang terlarut dalam perairan. Berdasarkan hasil pengukuran, kadar DO masing-masing stasiun bervariasi. Pada stasiun 1 nilai DO sebesar 7,24 mg/L, stasiun 2 sebesar $6,88 \mathrm{mg} / \mathrm{L}$, dan stasiun 3 sebesar $6,66 \mathrm{mg} / \mathrm{L}$. Nilai tersebut masih memenuhi baku mutu perairan sesuai PP No.82 Tahun 2001 ( $6 \mathrm{mg} / \mathrm{L})$. Hal ini berarti bahwa kandungan oksigen terlarut di perairan tersebut masih baik baik untuk pertumbuhan organisme di dalamnya. Korelasi antara DO dan keanekaragaman ikan bernilai positif (berbanding lurus). Semakin tinggi kadar DO maka keanekaragaman semakin tinggi dan sebaliknya. Nilai DO perairan berkisar 5-8 $\mathrm{mg} / \mathrm{L}$ sehingga dapat mendukung kehidupan organisme secara normal, sedangkan kadar D0 3-5 mg/L merupakan titik krisis bagi organisme air (Odum, 1993).

Nilai Biologycal Oxygen Demand (BOD) biasanya ditunjukkan dengan BOD $_{5}$ yang berarti jumlah oksigen yang dibutuhkan oleh mikroorganisme selama 5 hari. Pada stasiun 1 kadar BOD sebesar 1,05 $\mathrm{mg} / \mathrm{L}$, stasiun 2 sebesar $0,84 \mathrm{mg} / \mathrm{L}$, dan stasiun 3 sebesar $1,11 \mathrm{mg} / \mathrm{L}$. Nilai tersebut masih sesuai dengan baku mutu perairan sesuai PP No.82 Tahun 2001 yaitu sebesar 2,00 mg/L. Hal ini berarti bahwa perairan tersebut masih layak untuk mendukung kehidupan organisme air di dalamnya. Semakin tinggi nilai BOD maka dapat diketahui bahwa aktivitas mikroorganisme dalam menguraikan bahan organik semakin tinggi, dan sebaliknya (Efendi, 2003). BOD memiliki korelasi negatif (berbanding terbalik) terhadap H'ikan yang berarti semakin tinggi nilai BOD maka jumlah oksigen yang dibutuhkan mikroorganisme semakin banyak sehingga kadar DO berkurang dan keanekaragaman berkurang.

Kadar karbondioksida merupakan faktor pembatas, karena jika kadar karbondioksida tinggi berarti kadar oksigen terlarutnya rendah dan organisme dapat mengalami kematian. Artinya bahwa karbondioksida dan kenaekaragaman memiliki korelasi yang negatif atau berbanding terbalik. Berdasarkan hasil pengukuran, stasiun 1 memiliki kadar $\mathrm{CO}_{2}$ sebesar $19 \mathrm{mg} / \mathrm{L}$, stasiun 2 sebesar 20,6 mg/L, dan stasiun 3 sebesar 23,3 mg/L. Kandungan karbondioksida yang baik untuk 
organisme air yaitu tidak lebih dari $25 \mathrm{mg} / \mathrm{L}$. Jika lebih dari itu dapat menghambat pengikatan oksigen. Hal ini dikarenakan kandungan karbondioksida dalam air merupakan fungsi dari aktivitas biologi dan laju respirasinya melebihi fotosintesis (Soeyasa, 2001). Berdasarkan batas maksimal tersebut, maka perairan Sungai Keyang masih dapat mendukung kehidupan organisme di dalamnya.

Perairan yang produktif memiliki kisaran pH 68,5. Rata-rata reproduksi dan pemijahan ikan akan mengalami kenaikan pada $\mathrm{pH} 6$ meskipun semua tergantung pada jenis ikan. Berdasarkan hasil pengamatan nilai $\mathrm{pH}$ air di Sungai Keyang relatif konstan yaitu asam $(\mathrm{pH}=6)$. Hal ini terjadi karena reaksi kimiawi di dalam air, kandungan bahan organik dan proses degradasi bahan anorganik masih stabil di semua stasiun pengamatan (Gitarama dkk., 2016). Baku mutu sesuai PP No.82 Tahun 2001 nilai pH berkisar 6-9, sehingga dapat diketahui bahwa perairan ini masih cukup baik untuk mendukung kehidupan organisme air di dalamnya. Nilai pH perairan relatif asam karena berada dekat dengan vegetasi daratan seperti area pertanian (sawah, ladang) serta pemukiman warga yang memiliki kandungan asam lebih tinggi.
Pengaruh faktor fisika kimia air terhadap keanekaragaman ikan di Sungai Keyang dapat diketahui dengan melakukan uji T untuk mengetahui beda signifikan antara hasil pengamatan dengan masing-masing parameter. Berdasarkan hasil analisis tersebut diperoleh nilai signifikansi yang berbedabeda. Semua parameter yang diamati memiliki nilai sig <0,05 (derajat kepercayaan 95\%). Hal ini berarti bahwa terdapat perbedaan yang signifikan antara hasil pengamatan keragaman ikan dengan parameter fisika kimia tersebut. Artinya bahwa adanya perubahan pada kondisi fisika kimia lingkungan akan mempengaruhi keanekaragaman ikan baik itu pengaruh negatif atau positif. Perubahan faktor fisika dan kimia suatu perairan dapat terjadi karena adanya pencemaran salah satunya yaitu pencemaran bahan organik. Tingginya kandungan bahan organik berasal dari limbah rumah tangga, sisa-sisa pupuk pertanian, serta aktivitas seperti mandi di sungai. Semakin tinggi kandungan bahan organik di suatu perairan maka kandungan DO nya semakin rendah, dan sebaliknya.

Hubungan antara parameter fisika kimia dan keanekaragaman ikan dapat diketahui berdasarkan hasil uji regresi dan korelasi pearson seperti pada Tabel 4.

Tabel 4. Hasil Uji Korelasi dan Regresi antara Parameter Fisik Kimia dan H'ikan

\begin{tabular}{|c|c|c|c|c|c|}
\hline Parameter & Sig & $\begin{array}{c}\text { Nilai } \\
\text { korelasi }\end{array}$ & Arah & Kategori & $\begin{array}{c}\text { Besar pengaruh terhadap } \\
\text { H' ikan (\%) }\end{array}$ \\
\hline DO & 0,869 & 0,024 & Positif & Rendah & 4,2 \\
\hline BOD & 0,190 & $-0,956$ & Negatif & Sangat Kuat & 91.3 \\
\hline $\mathrm{CO}_{2}$ & 0,708 & $-0,443$ & Negatif & Sedang & 19,6 \\
\hline Suhu & 0,636 & 0,541 & Positif & Sedang & 29,2 \\
\hline Kecerahan & 0,562 & $-0,635$ & Negatif & Kuat & 40,3 \\
\hline Kekeruhan & 0,532 & $-0,671$ & Negatif & Kuat & 45 \\
\hline TDS & 0,583 & $-0,609$ & Negatif & Kuat & 37,1 \\
\hline
\end{tabular}

Faktor lingkungan dan keanekaragaman memiliki pengaruh yang signifikan jika nilai sig<0,05. Berdasarkan hasil analisis korelasi pada Tabel $4 \mathrm{di}$ atas, diketahui bahwa semua parameter fisik kimia dengan indeks keanekaragaman ikan $\left(\mathrm{H}^{\prime}\right)$ memiliki korelasi yang tidak signifikan karena nilai sig>0,05. Korelasi bernilai positif berarti bahwa hubungan antara faktor fisika kimia dengan keanekaragaman ikan berbanding lurus. Semakin tinggi nilai DO selama masih dalam ambang batas maka keanekaragaman ikan semakin tinggi dan sebaliknya. Korelasi negatif berarti bahwa hubungan antara faktor fisika kimia dengan keanekaragaman ikan berbanding terbalik, artinya semakin tinggi nilai faktor fisika kimia maka nilai keanekaragaman semakin rendah, dan sebaliknya. Semakin tinggi nilai kekeruhan maka nilai keanekaragaman semakin rendah.

Nilai besar pengaruh faktor lingkungan terhadap H'ikan dapat diketahui dengan melakukan uji regresi menggunakan program SPSS versi 16. Hasil uji regresi pada Tabel 4 menunjukkan bahwa pengaruh terbesar yaitu BOD sebanyak 91,3\%. BOD merupakan banyaknya oksigen yang dibutuhkan untuk pemecahan bahan organik sebagai bahan makanan. Perairan Sungai Keyang mengalami pencemaran sedang hingga berat oleh bahan organik. Semakin banyak kandungan bahan organik maka oksigen yang dibutuhkan juga semakin banyak (Salmin, 2005). DO memiliki pengaruh yang terkecil karena nilai DO relatif sama dan masih dalam batas kelayakan untuk pertumbuhan ikan. Parameter lingkungan yang memiliki pengaruh dominan $(>50 \%)$ yaitu hanya BOD.

\section{Kesimpulan}

Berdasarkan hasil penelitian yang telah dilakukan maka dapat diperoleh simpulan yaitu keanekaragaman ikan di Sungai Keyang termasuk dalam kategori sedang. Zonasi Keanekaragaman ikan didominasi oleh genus Poecillia dan Rasbora. Pola migrasi masing-masing spesies ikan berbeda yaitu ada yang selalu di tepi dan ada yang menyebar baik untuk tujuan reproduksi atau mencari makan. C. striata lebih suka menyebar di 
Pratami, V. A. Yulia., Setyono, P dan Sunarto. (2018). Zonasi, Keanekaragaman Dan Pola Migrasi Ikan Di Sungai Keyang, Kabupaten Ponorogo, Jawa Timur. Jurnal IImu Lingkungan. 16(1), 78-85, doi:10.14710/jil.16.1.78-85

semua badan air, sedangkan ikan $P$. reticulata lebih suka di tepi dan permukaan air.

\section{DAFTAR PUSTAKA}

Araujo, F.G., I. Fichberg., B.C.T.Pinto., and M.G.Peixoto. 2003. A Preliminary Index of Biotic Integrity for Monitoring The Condition of The Rio Paraiba do Sul, Southeast Brazil. Environmental Management. 32 (4), 516-526.

Astirin, O.P. dan A.D. Setyawan. 2000. Biodiversitas Plankton di Waduk Penampung Banjir Jabung, Kabupaten Lamongan dan Tuban. Biodiversitas. 1(2), 65-71.

Azmi, N., Yunashfi., dan A. Muhtadi. 2015. Struktur Komunitas Nekton di Danau Pondok Lapan Desa Naman Jahe Kecamatan Salapian Kabupaten Langkat. Sumatera Utara: Universitas Sumatera Utara.

Chandra, S and T.K.Banarjee. 2004. Histopathological Analysis Of The Respiratory Organs Of Channa striata Subjected To Air Exposure. Veterinarski Arhiv. 74 (1), 37-52.

Dinas Perikanan Provinsi Daerah Tingkat I Jambi. 1995. Pengenalan Jenis - Jenis Ikan Perairan Umum Jambi Bagian 1 Ikan-Ikan Sungai Utama Batang Hari Jambi. Pemda Tingkat I Jambi. hlm. 17-19.

Djajasmita, M., F. Sabar., dan S. Wirjoatmojo. 1987. Ekologi Ikan Kehkel (Glyptothorax platypogon) di Sungai Cisadane. Zoo Indonesia Balitang Zoologi. LIPI Bogor.

Djumanto dan F. Setyawan. 2009. Food Habits Of The Yellow Rasbora, Rasbora lateristriata, Broodfish During Moving To Spawning Ground. Journal of Fisheries Sciences. 11(1), 133145.

Effendi, H. 2003. Telaah Kualitas Air Bagi Pengelolaan Sumber Daya dan Lingkungan Perairan. Yogyakarta. Penerbit Kanisius.

Fahmi, M.R. (2010), Phenotypic Platisity Kunci Sukses Adaptasi Ikan Migrasi: Studi Kasus Ikan Sidat (Anguilla sp .). Prosiding Forum Inovasi Teknologi Akuakultur. pp: 9-17.

Gitarama, A.M., M. Krisanti., dan D.R.Agungpriyono. 2016. Komunitas Makrozoobentos dan Akumulasi Kromium di Sungai Cimanuk Lama, Jawa Barat. Jurnal Ilmu Pertanian Indonesia (JIPI). 21(1), 48-55.

Grosse, J., P.V.Breugel., and H.T.S.Boschker. 2015. Tracing Carbon Fixation In Phytoplankton-Compound Specific And Total ${ }^{13} \mathrm{C}$ Incorporation Rates. Limnology and Oceanography:Method. 13, 288-302.

Haji, A.T.S., R. Wirosoedarmo., dan L.R.Syiama. 2012. Prognosis Banjir Sub-Sub DAS Keyang Menggunakan Simodas untuk Kajian Lingkungan Hidup Strategis terhadap Rencana Tata
Ruang Wilayah Kabupaten Ponorogo. Jurnal Teknologi Pertanian. 13 (1), 43-51.

Hartoto, D.I. dan E. Mulyana (1996), Hubungan Parameter Kualitas Air Dengan Struktur Ikhtiofauna Perairan Darat Pulau Siberut. Oseanologi dan Limnologi di Indonesia. 29, 41-55.

Indriyanto. 2012. Ekologi Hutan. Jakarta. Bumi Aksara.

Kottelat, M., Whitten, A.J., Kartikasari, S.N., dan S, Wirjoatmodjo. (1993) Ikan Air Tawar Indonesia Bagian Barat dan Sulawesi. Jakarta. CV. Java Books.

Kuan-Chung Li., B. Shieh., Yuh-wen Chiu., Da-ji Huang., and Shihhsiung Liang. 2016. Growth, Diet Composition and Reproductive Biology of the Invasive Freshwater Fish Chevron snakehead Channa striata on a Subtropical Island. Zoological Studies. 55 (53), 1-11.

Listyanto, N. dan S. Andriyanto. 2009. Ikan Gabus (Channa striata) manfaat pengembangan dan alternatif teknik budidayanya. Media Akuakultur. 4(1), 18-25.

Lubis, M.Z. and S. Pujiyati. 2013. The Impact Of Acclimatization Of Various Salinity To Againts Mortalitas Rate And Behaviour Fish Guppy (Poecilia reticulata) As A Subtitute For Fish Bait Skipjack (Katsuwonus pelamis). Jurnal Teknologi Perikanan dan Kelautan. 4 (2), 109-115.

Munarto. 2010, Studi Kominutas Gastropoda di Situ Salam Kampus Universitas Indonesia, Depok. Tesis. Program Studi Biologi Fakultas Matematika dan Ilmu Pengetahuan Alam Universitas Indonesia. Depok.

Nelson, A.F.M., R. Perissinotto., and C.C.Appleton. 2010. Salinity and Temperature Tolerance of the Invasive Freshwater Gastropod Tarebia granifera. South African Journal of Science. 106 (3/4), 1-7.

Odum, E.P. 1993. Dasar-Dasar Ekologi. Yogyakarta. Universitas Gadjah Mada Press.

Salmin. 2005, Oksigen Terlarut (DO) dan Kebutuhan Oksigen Biologi (BOD) Sebagai Salah Satu Indikator Untuk Menentukan Kualitas Perairan. Oseana. 30 (3), 21-26.

Sentosa, A.A., dan Djumanto. 2010. Habitat Pemijahan Ikan Wader Pari (Rasbora lateristriata) Di Sungai Ngrancah, Kabupaten Kulon Progo. Jurnal Iktiologi Indonesia. 10(1), 55-63.

Soeyasa. 2001. Ekologi Perairan. Jakarta. Departemen Kelautan dan Perikanan Dirjen. Pendidikan Menengah Atas.

Weber, S.P.K., and L.K.Duffy. 2007. Effects of Total Dissolved Solids on Aquatic Organisms: A Review of Literature and Recommendation for Salmonid Species. American Journal of Environmental Sciences. 3(1), 1-6.

Wetzel,R.G., and Gene,E.L. (2000) Lymnological Analyses. 3rd edition. Springer Science and Business Media, US 